\title{
The Effect of Metformin and Glimepiride on Platelet Count and Indices Among Diabetic Patients Attending Jaber Abu Aliz Diabetic Center in Khartoum State
}

Hussein Abker Hussein ( $\nabla$ hussienabkar4@gmail.com )

sudan international university https://orcid.org/0000-0001-7101-2162

Dalia Mohammed Babikir

hematoloy deparrtment - Sudan international university, khartoum -sudan

Fatima-Elzhra Ahmed Elmagzoub

hematolgy department - Sudan international university, Khartoum-sudan

Mouna Adel Samaan

Assistant Professor - The National Ribat University Khartoum Sudan

\section{Research}

Keywords: Diabetes Mellitus, Metformin, Glimepiride, platelet count and indices

Posted Date: March 15th, 2021

DOI: https://doi.org/10.21203/rs.3.rs-294781/v1

License: (c) (i) This work is licensed under a Creative Commons Attribution 4.0 International License.

Read Full License 


\section{Abstract}

\section{Background}

Diabetes mellitus (DM) is a global pandemic, Platelets have crucial role in accelerated atherosclerosis and thrombosis which characterize DM.

\section{Aim}

The aim of the study was to detect the effect of two major oral hypoglycemic drugs (Metformin and Glimepiride) on platelet count and indices MPV (Mean platelet volume), PLCR (platelet large cell ratio), PDW (platelet distribution width). Beside, to study the effects of variation in Age, sex, duration of the drug, dose of drug, HbA1C level and associated complications.

\section{Material and methods}

96 diabetic patients have been included in this study in addition 50 apparently healthy non-diabetic matching for age and sex subjects have been tested as control group.

EDTA anti-coagulated venous blood samples has been taken from each, platelet count and indices were measured using automatic blood counter (Sysmex KX-21N) and HbA1C was Measured using Ichroma II . Statistics was performed by SPSS (version 22).

\section{Results}

The results showed that both types of treatment have reduced platelets indices but the reduction in Glimepiride was insignificant except in PDW when compared with control. Also both have no effect on platelet count. Both treatments have insignificant variation on measured parameters when considering age, gender, dose and treatment duration though significant variation in Glimepiride study population was detected due to associated complications and $\mathrm{HbA} 1 \mathrm{C}$ level.

\section{Conclusion}

It is concluded that both types of drugs reduce platelet indices which have a good prognostic effect on the Pro-thrombotic state and accelerated atherosclerosis which is associated with type 2 Diabetic patients. Metformin have better effect on platelet indices than Glimepiride. Further case control trails are required.

\section{Background}

DM is a chronic disease characterized by increased blood glucose level ${ }^{(1)}$. Approximately $90-95 \%$ of diabetic patients are type $2 \mathrm{DM}$ which is caused by insulin resistance ${ }^{(2)}$. Chronic complications of DM are vascular or nonvascular. Vascular complications are further subdivided into macro vascular (coronary 
artery disease, peripheral vascular disease, and cerebrovascular disease) or micro vascular (retinopathy, neuropathy, and nephropathy) ${ }^{(2,3)}$.

Automated blood counters rapidly measure Platelet count and indices (MPV, PDW, and P- LCR) which are features of platelet activation. MPV (Mean platelet volume) determine the platelet volume and reported by analyzing the platelet distribution curve, PDW (platelet distribution width) is an indicator for variation in the platelet size and it is calculated at $20 \%$ relative height in platelet size distribution curve. P-LCR (platelet-large cell ratio) is discriminate of the circulating larger platelets $(>12 \mathrm{fL}$ ), which is measured by fixed discriminator at $12 \mathrm{fL}$ and reported as percentage ${ }^{(4)}$.

The platelets have important roles in normal homeostasis and atherosclerosis process ${ }^{(5,6)}$. MPV is increased in patients at a high risk for athero-thrombotic diseases ${ }^{(7)}$. DM has been considered as a 'pro thrombotic state' with increased in thrombocytes reactivity ${ }^{(8,9)}$. MPV is increased in patients with type 2 DM ${ }^{(10)}$ Researchers also found that PDW and PLCR were all increased in diabetic patients. PDW was decreased in those without complications in contrast to those with micro vascular complications of DM (11). An increased MPV is a risk marker for platelet activation ${ }^{(7)}$.

However, whether oral hypoglycemic drugs (Metformin and Glimepiride) can effectively prevent thrombosis or reduce Micorvascular and Macrovascular complications or not currently, there is no available study on the effect of diabetes mellitus hypoglycemic drugs on platelets count and indices among Sudanese population.

This study was conducted to explore the effect of diabetes mellitus treatments (Metformin and Glimepiride) on platelet count and indices (MPV, PLCR, PDW).Beside the effect of Age, sex, dose and duration of the drug used, associated complications, $\mathrm{HbA} 1 \mathrm{C}$ level were also explored.

\section{Methods}

A cross-sectional descriptive study was carried out on a group of 96 Sudanese patients diagnosed with Type 2 diabetes, 50 under Metformin and 46 under Glimepiride treatment who attended Jaber Abu Aliz Diabetic Center in Khartoum State during the period of 6 months from March to September 2020 .An age, and sex-matched control group consisting of 50 healthy control were also tested. Excluding NonSudanese ,Subjects with renal failure, cancer, hepatic ,malaria infected or treated patients in last 7days, hematological disorders, pregnancy and a history of drug used affect platelets count or indices (aspirin, warfarin, heparin, statin, anticoagulant medications) and those younger than 18 years were excluded from the study.

Approvals have been taken from Khartoum State Ministry of Health Research Department, and verbal consent has been taken from each participant volunteer. The samples have collected from participants under COVID 19 outbreak Precautions by administered written questionnaire. 
On $5 \mathrm{ml}$ EDTA anticoagulated venous blood sample, platelet count and indices were measured by automatic blood counter (Sysmex KX-21N) for type2 DM patients and controls, and also HbA1C was measured by Ichroma II for DM patient's blood samples.

Statistical analysis was performed by statistical package for the social sciences (SPSS) version 22, Student's independent sample two-tailed t-test for comparisons of two groups, differences based on patient characteristic measurements were analyzed by one-way analysis of variance (ANOVA) for more than two groups. The findings were mean \pm standard deviation. And the P-value $<0.05$ was considered statistically significant.

\section{Result}

DM patients under Metformin hypoglycemic drug (Group A) and DM patients under Glimepiride (Group B) were categorized into groups according to Age, sex, diabetes chronic complications, dose per day, duration of Metformin or Glimepiride used and the level of Hb A1C.

patients using Metformin were 26 females and 24 males with mean age of 55.4 years old, $22 \%$ of them were us $500 \mathrm{mg}$ and $78 \%$ taking $850 \mathrm{mg}$ Metformin. Patients on Glimepiride were 27 females and 19 males and 27 females with mean age of 56.4 years old taking diffferent doses $(2 \mathrm{mg}=17.3 \%, 3 \mathrm{mg}=$ $10.9 \%, 4 \mathrm{mg}=65.2 \%, 5 \mathrm{mg}=6.6 \%)$.

Study population ages were categorized into less than $40,40-50,<50-60,<60-70$ and more than 70 years their frequencies were [Metformin $=(2 \%, 36 \%, 38 \%, 16 \%, 8 \%)$, Glimepiride $=(6.6 \%, 28.9 \%, 33.4 \%$, $24.5 \%, 6.6 \%)$,respectively.

drugs durations were divided in to less than $5,5-10,<10-15,<15-20$ and more than 20 years their percentages were [Metformin $=(30 \%, 36 \%, 12 \%, 14 \%, 8 \%)$, Glimepiride $=(44 \%, 39 \%, 9 \%, 7 \%$, $2 \%)$,respectively. According to the presence of associated complications in Metformin's and Glimepiride's study populations $10 \%$ and $4 \%$, were with retinopathy, $20 \%$ and $40 \%$ with foot ulcer and patients with no detected complications were $70 \%, 56 \%$, respectively.

DM Patients with $\mathrm{HbA} 1 \mathrm{C}$ less than $6 \%$ were $15 \%, 6-7 \%$, were $16 \%$ and more than $7 \%$ were $69 \%$.

The mean, standard deviation and P-value of the measured platelet count and indices of the study population and compared with the control group are shown in table (1). 
Table 1

Comparison in platelet count and indices between oral hypoglycemic drugs study population and control group

\begin{tabular}{|lllllll|}
\hline Parameters & $\begin{array}{l}\text { Mean } \\
\text { Metformin } \pm \\
\text { SD } \\
\text { (Group A) }\end{array}$ & $\begin{array}{l}\text { Mean } \\
\text { Glimepiride } \pm \\
\text { SD } \\
\text { (Group B) }\end{array}$ & $\begin{array}{l}\text { Mean Non } \\
\text { diabetes } \pm \text { SD } \\
\text { (Group C) }\end{array}$ & $\begin{array}{l}\text { p.value } \\
\text { (A vs } \\
\text { C) }\end{array}$ & $\begin{array}{l}\text { p.value } \\
\text { (B vs } \\
\text { C) }\end{array}$ & $\begin{array}{l}\text { p.value } \\
\text { (A vs } \\
\text { B) }\end{array}$ \\
\hline $\begin{array}{l}\text { Platelet } \\
\text { count }\left(\mathrm{x} 10^{9} / \mathrm{I}\right)\end{array}$ & $319.2 \pm 138.6$ & $298 \pm 114$ & $280.1 \pm 77.7$ & .087 & .378 & .423 \\
\hline MPV ( fl) & $9 \pm .83$ & $9.4 \pm .93$ & $9.7 \pm .86$ & .000 & .153 & .044 \\
\hline PDW ( fl) & $10 \pm 1.2$ & $11 \pm 1.9$ & $11.8 \pm 1.6$ & .000 & .028 & .004 \\
\hline P-LCR $(\%)$ & $17.8 \pm 6.5$ & $20.7 \pm 7.2$ & $22.9 \pm 6.4$ & .000 & .117 & .039 \\
\hline
\end{tabular}

p. value $<0.05$ is considered significant $S D=$ standard deviation 
Table 2

comparisons between platelet count and platelet indices in DM patients using Metformin as oral hypoglycemic drug according to age, gender, complications, dose, Metformin using duration and HbA1C groups.

\begin{tabular}{|c|c|c|c|c|c|}
\hline Characteristic & groups & $\begin{array}{l}\text { Mean Platelet } \\
\text { count } \\
\left(\times 10^{9} / \mathrm{I}\right) \pm \text { S.D }\end{array}$ & $\begin{array}{l}\text { Mean MPV ( } \\
\text { fl) } \pm \text { S.D }\end{array}$ & $\begin{array}{l}\text { Mean PDW( fl) } \\
\pm S . D\end{array}$ & $\begin{array}{l}\text { Mean P- } \\
\text { LCR (\%) } \\
\pm \text { S.D }\end{array}$ \\
\hline \multirow[t]{5}{*}{ Age (years) } & 40 to 50 & $298.39 \pm 76.1$ & $9.38 \pm .9$ & $10.6 \pm 1.7$ & $20.25 \pm 6.8$ \\
\hline & $>50$ to 60 & $\begin{array}{l}346.26 \pm \\
194.9\end{array}$ & $8.97 \pm .8$ & $10.2 \pm 1.6$ & $16.87 \pm 6.5$ \\
\hline & $>60$ to 70 & $\begin{array}{l}319.88 \pm \\
123.2\end{array}$ & $8.68 \pm .6$ & $10.8 \pm 2.5$ & $16.21 \pm 3.4$ \\
\hline & $\begin{array}{l}\text { more than } \\
70\end{array}$ & $261.25 \pm 57.1$ & $8.98 \pm .7$ & $10.38 \pm 1.5$ & $16.18 \pm 8.2$ \\
\hline & p.value & .492 & .199 & .871 & .299 \\
\hline \multicolumn{6}{|l|}{ Gender } \\
\hline & Male & $\begin{array}{l}303.96 \pm \\
132.8\end{array}$ & $9.05 \pm .97$ & $10.8 \pm 2$ & $18.09 \pm 7.5$ \\
\hline & Female & $\begin{array}{l}333.27 \pm \\
144.9\end{array}$ & $9.05 \pm .7$ & $10 \pm 1.3$ & $17.5 \pm 5.4$ \\
\hline & p.value & .461 & .987 & .099 & .751 \\
\hline \multicolumn{6}{|l|}{ Complications } \\
\hline & Eye & $222.8 \pm 55.7$ & $9.66 \pm .38$ & $10.54 \pm .75$ & $22.14 \pm 2.8$ \\
\hline & Foot & $437.6 \pm 238.4$ & $8.7 \pm .92$ & $9.47 \pm 1.3$ & $14.97 \pm 7.3$ \\
\hline & $\begin{array}{l}\text { No } \\
\text { complication }\end{array}$ & $299.14 \pm 79.8$ & $9.06 \pm .82$ & $10.7 \pm 1.9$ & $17.97 \pm 6.3$ \\
\hline & p.value & .050 & .107 & .171 & .123 \\
\hline \multicolumn{6}{|l|}{ Dose (day) } \\
\hline & $500 \mathrm{mg}$ & $\begin{array}{l}309.87 \pm \\
136.4\end{array}$ & $8.98 \pm .7$ & $10.38 \pm 1.8$ & $17.14 \pm 5.9$ \\
\hline & $850 \mathrm{mg}$ & $\begin{array}{l}352.27 \pm \\
147.7\end{array}$ & $9.28 \pm 1.1$ & $10.48 \pm 1.9$ & $20.09 \pm 8.1$ \\
\hline & p.value & .376 & .297 & .452 & .184 \\
\hline \multicolumn{6}{|l|}{$\begin{array}{l}\text { Metformin's } \\
\text { duration }\end{array}$} \\
\hline & less than 5 & $267.2 \pm 66.5$ & $8.99 \pm .82$ & $10.5 \pm 1.8$ & $17.28 \pm 6.9$ \\
\hline
\end{tabular}




\begin{tabular}{|c|c|c|c|c|c|}
\hline \multirow[t]{6}{*}{ Characteristic } & groups & $\begin{array}{l}\text { Mean Platelet } \\
\text { count } \\
\left(\times 10^{9} / \mathrm{I}\right) \pm \text { S.D }\end{array}$ & $\begin{array}{l}\text { Mean MPV ( } \\
\text { fl) } \pm \text { S.D }\end{array}$ & $\begin{array}{l}\text { Mean PDW(fl) } \\
\pm \text { S.D }\end{array}$ & $\begin{array}{l}\text { Mean P- } \\
\text { LCR (\%) } \\
\pm \text { S.D }\end{array}$ \\
\hline & 5 to 10 & $\begin{array}{l}315.78 \pm \\
111.8\end{array}$ & $9.17 \pm .98$ & $10.4 \pm 2$ & $18.71 \pm 6.9$ \\
\hline & 10 to 15 & $433.83 \pm 245$ & $9.02 \pm .95$ & $10.2 \pm 1.6$ & $16.52 \pm 8.3$ \\
\hline & 15 to 20 & $\begin{array}{l}295.57 \pm \\
121.7\end{array}$ & $8.96 \pm .45$ & $10.5 \pm 1.5$ & $17.69 \pm 3.5$ \\
\hline & $\begin{array}{l}\text { more than } \\
20\end{array}$ & $399 \pm 207$ & $8.95 \pm .86$ & $10.1 \pm 1.7$ & $17.6 \pm 6.7$ \\
\hline & p.value & .330 & .967 & .993 & 957 \\
\hline \multicolumn{6}{|l|}{$\mathrm{Hb}$ A1c } \\
\hline \multirow[t]{4}{*}{$(\%)$} & less than $6 \%$ & $\begin{array}{l}385.76 \pm \\
244.9\end{array}$ & $9.24 \pm .82$ & $10.3 \pm 1.4$ & $18.9 \pm 6$ \\
\hline & 6 to $7 \%$ & $273.5 \pm 57.6$ & $9.3 \pm .6$ & $10.6 \pm 1.6$ & $20 \pm 4.8$ \\
\hline & $\begin{array}{l}\text { More than } \\
7 \%\end{array}$ & $316.8 \pm 118.4$ & $8.9 \pm .89$ & $10.4 \pm 1.9$ & $16.8 \pm 6.9$ \\
\hline & p.value & .414 & .365 & .912 & .343 \\
\hline
\end{tabular}


Table 3

comparison between platelet count and platelet indices in DM patients using Glimepiride as oral hypoglycemic drug according to age, gender, complications, dose, Glimepiride using duration and HbA1C groups.

\begin{tabular}{|c|c|c|c|c|c|}
\hline \multirow[t]{2}{*}{ Characteristic } & \multirow[t]{2}{*}{ groups } & \multirow[t]{2}{*}{$\begin{array}{l}\text { Mean Platelet count (X } \\
\left.10^{9} / \mathrm{I}\right) \pm \text { S.D }\end{array}$} & \multirow[t]{2}{*}{$\begin{array}{l}\text { Mean MPV( } \\
\text { fl) } \pm \text { S.D }\end{array}$} & $\begin{array}{l}\text { Mean } \\
\operatorname{PDW}(f)\end{array}$ & \multirow[t]{2}{*}{$\begin{array}{l}\text { Mean P-LCR } \\
(\%) \pm S . D\end{array}$} \\
\hline & & & & $\pm S . D$ & \\
\hline \multirow[t]{6}{*}{ Age (years) } & Less than 40 & $250 \pm 90.4$ & $10 \pm .32$ & $\begin{array}{l}12.27 \pm \\
1.4\end{array}$ & $22.8 \pm 8.4$ \\
\hline & 40 to 50 & $266.8 \pm 79.25$ & $9.5 \pm 1$ & $11 \pm 1.9$ & $21.5 \pm 7.8$ \\
\hline & $>50$ to 60 & $337.6 \pm 146.95$ & $9.2 \pm 1.1$ & $\begin{array}{l}10.6 \pm \\
2.5\end{array}$ & $19.2 \pm 8.5$ \\
\hline & $>60$ to 70 & $303.3 \pm 105.46$ & $9.3 \pm .72$ & $\begin{array}{l}10.7 \pm \\
1.4\end{array}$ & $20 \pm 4.8$ \\
\hline & $\begin{array}{l}\text { more than } \\
70\end{array}$ & $288.3 \pm 78.5$ & $9.4 \pm .78$ & $\begin{array}{l}11.7 \pm \\
1.7\end{array}$ & $22 \pm 7.5$ \\
\hline & p.value & .500 & .675 & .681 & .881 \\
\hline \multicolumn{6}{|l|}{ Gender } \\
\hline & Male & $288.4 \pm 288.40$ & $9.1 \pm .92$ & $\begin{array}{l}10.5 \pm \\
1.7\end{array}$ & $18.99 \pm 6.68$ \\
\hline & Female & $309.7 \pm 103.94$ & $9.6 \pm .93$ & $11.3 \pm 2$ & $21.67 \pm 7.6$ \\
\hline & p.value & .535 & .117 & .181 & .216 \\
\hline \multicolumn{6}{|l|}{ Complications } \\
\hline & Foot & $351.7 \pm 141.15$ & $8.9 \pm .87$ & $\begin{array}{l}9.97 \pm \\
1.4\end{array}$ & $17.2 \pm 5.9$ \\
\hline & $\begin{array}{l}\text { No } \\
\text { complication }\end{array}$ & $269.4 \pm 79.67$ & $9.7 \pm .89$ & $11.6 \pm 2$ & $22.6 \pm 7.4$ \\
\hline & p.value & .034 & .007 & .006 & .014 \\
\hline \multicolumn{6}{|l|}{ Dose (day) } \\
\hline & $2 \mathrm{mg}$ & $266.38 \pm 107.7$ & $9.8 \pm 1$ & $\begin{array}{l}11.7 \pm \\
2.3\end{array}$ & $24.25 \pm 8.46$ \\
\hline & $3 \mathrm{mg}$ & $273.8 \pm 112$ & $9.2 \pm .95$ & $\begin{array}{l}10.16 \pm \\
1.5\end{array}$ & $18.5 \pm 6.9$ \\
\hline & $4 \mathrm{mg}$ & $318.2 \pm 117.5$ & $9.3 \pm .96$ & $\begin{array}{l}10.8 \pm \\
1.98\end{array}$ & $19.6 \pm 7.16$ \\
\hline & $5 \mathrm{mg}$ & $258 \pm 110.1$ & $9.5 \pm .23$ & $\begin{array}{l}11.7 \pm \\
1.35\end{array}$ & $22.4 \pm 2.78$ \\
\hline
\end{tabular}




\begin{tabular}{|c|c|c|c|c|c|}
\hline Characteristic & groups & $\begin{array}{l}\text { Mean Platelet count }(x \\
\left.10^{9} / I\right) \pm \text { S.D }\end{array}$ & $\begin{array}{l}\text { Mean MPV( } \\
\text { fl) } \pm S . D\end{array}$ & $\begin{array}{l}\text { Mean } \\
\text { PDW( fl) } \\
\pm \text { S.D }\end{array}$ & $\begin{array}{l}\text { Mean P-LCR } \\
(\%) \pm S . D\end{array}$ \\
\hline & p.value & .559 & .548 & .468 & .377 \\
\hline \multicolumn{6}{|l|}{$\begin{array}{l}\text { Glimepiride's } \\
\text { duration }\end{array}$} \\
\hline & less than 5 & $285.7 \pm 84.9$ & $9.3 \pm .85$ & $\begin{array}{l}10.6 \pm \\
1.5\end{array}$ & $19.4 \pm 6.4$ \\
\hline & 5 to 10 & $298.3 \pm 110.2$ & $9.4 \pm 1.16$ & $\begin{array}{l}11.4 \pm \\
2.6\end{array}$ & $21.5 \pm 9$ \\
\hline & 10 to 15 & $247.3 \pm 16.7$ & $9.6 \pm .52$ & $\begin{array}{l}10.8 \\
\pm .68\end{array}$ & $21.1 \pm 3.1$ \\
\hline & 15 to 20 & $488.7 \pm 242.3$ & $9 \pm .46$ & $\begin{array}{l}10.4 \pm \\
1.2\end{array}$ & $17.6 \pm 4$ \\
\hline & p.value & .021 & .880 & .408 & .746 \\
\hline \multicolumn{6}{|l|}{$\mathrm{Hb} \mathrm{A1c}$} \\
\hline \multirow[t]{4}{*}{$(\%)$} & less than $6 \%$ & $222.7 \pm 65.9$ & $10.2 \pm 1.1$ & $\begin{array}{l}12.8 \pm \\
2.4\end{array}$ & $27.7 \pm 8.8$ \\
\hline & 6 to $7 \%$ & $305.8 \pm 70.9$ & $9.5 \pm 1$ & $\begin{array}{l}10.9 \pm \\
1.8\end{array}$ & $20.5 \pm 7.7$ \\
\hline & $\begin{array}{l}\text { More than } \\
7 \%\end{array}$ & $315.4 \pm 120.4$ & $9.2 \pm .84$ & $\begin{array}{l}10.6 \pm \\
1.7\end{array}$ & $19 \pm 6.1$ \\
\hline & p.value & .145 & .034 & .016 & .012 \\
\hline
\end{tabular}

Statistically insignificance difference was detected on platelet count between patients took Metformin, Glimepiride and healthy controls. Both drugs have reduced platelet indices (MPV, PLCR, PDW) when compared with the control group but platelet indices were much more reduced in patients using Metformin than those taking Glimepiride as oral hypoglycemic drug as shown in (Table 1).

There was insignificant difference in platelet count and indices among those using Metformin in term of sex, age, dose, drug duration, associated complications and HbA1C level as shown in (Table 2). But among those using Glimepiride as oral hypoglycemic drug, there was increased platelet count and decreased platelet indices in patients with foot ulcers than patients without complications. Also increased platelet indices in patients with $\mathrm{HbA} 1 \mathrm{C}$ level less than $6 \%$ in contrast to those with $\mathrm{HbA} 1 \mathrm{C}$ more than $7 \%$.

Glimepiride diabetic patients from 15 to 20 years old have increased platelet count (488.7) than patients used Glimepiride less than 15 years (247.3), less than 10 years (298.3) and less than 5 years (285.7). 
There was insignificant difference in term of age, gender, and dose in Glimepiride users as shown in (Table 3).

\section{Discussion}

A patient with DM has accelerated atherosclerosis $(12,13)$. The interference effects of oral hypoglycemic drugs (Metformin, Glimepiride) on the platelet count and indices are very important because platelets have direct impact in the pro thrombotic condition which characterizes patients with DM. Platelets of DM patients are characterized by problems in regulation of several signaling pathways leading to the acceleration of adhesion, activation and aggregation ${ }^{(13)}$. Thus, Platelet count, MPV, P-LCR and PDW were measured as a marker of production rate and platelet activation.

Both Metformin and Glimepiride have been found to have anti-thrombotic effect. Metformin has more anti thrombotic effect than Glimepiride. Patients used Metformin have reduced platelet indices when compared with Glimepiride and non-diabetic population.

These findings were supported by Dib et al. their study showed that the diabetic complications may increase MPV in DM patients and Metformin decreased the MPV Regardless of glucose lowering effect of the Metformin. These findings may provide a further explanation for the anti atherogenic effect of metformin ${ }^{(14)}$. Dolasık et al. also reported decreased MPV values in Metformin hypoglycemic drug group. Increased MPV appears to have a crucial role at the beginning of atherosclerosis development. This may help to understand the anti atherogenic effect of Metformin ${ }^{(15)}$. Also, Papazafiropoulou et al. demonstrated Metformin, sulfonylureas (Glimepiride) can reduce the cardiovascular risk in type 2 Diabetes Mellitus DM by exert a favorable effect on platelet function ${ }^{(16)}$.

The mechanism that Metformin inhibits the platelet activation is described by Xin et al., they found Metformin prevent platelet activation by inhibiting extracellular mitochondrial DNA (mtDNA) release (17).

Regarding Glimepiride mechanism of preventing thrombosis is reported by Yukio et al. they found that cyclooxygenase pathway is inhibited by Glimepiride, while the activities of 12-lipoxygenase and phospholipase A2 were unaffected thus, prevent the formation of thromboxane A2 from Arachidonic acid metabolism of human platelets. The main function of thromboxane A2 is platelet activation and aggregation ${ }^{(18)}$.

we compared different DM Patients groups using Glimepiride and Metformin according to (age, sex, dose, associated complications, duration of drug used, $\mathrm{Hb} \mathrm{A1C} \mathrm{level),} \mathrm{stable} \mathrm{anti} \mathrm{thrombotic} \mathrm{effect} \mathrm{was} \mathrm{found}$ among Metformin users because there were no significant differences in platelet count and indices (MPV, P-LCR and PDW) in term of above prescribed variables in contrast of Glimepiride which has variable a favorable anti thrombosis effect.

Mardia et al. found a high platelet count, PDW and PCT levels in DM patients with diabetic foot ulcers in contrast to DM patients without diabetic foot ulcers. It indicates that platelets are activated and increased 
its ability for aggregation ${ }^{(19)}$. In our findings Patients with diabetic foot using glimepiride showed high anti thrombotic effect with relatively increased platelet count and deceased indices than patients without complications. These results may explain that Glimepiride is not a drug of choice during diabetic foot complications when compared to Metformin because regardless the high platelet counts, platelet inactivation is insufficient.

BackSterner et al. found that increased platelet counts are a common finding in DM patients with nephropathy ${ }^{(20)}$. The in vivo generation of advanced glycation end products (AGEs) in the kidney is time dependent reported by Soulis et al. ${ }^{21)}$. they supported our finding regarding increased platelet count in DM patients used Glimepiride for more than 15 to 20 years.

Our results showed that platelet indices were decreased in patients with $\mathrm{HbA} 1 \mathrm{C}$ more than $7 \%$ and increased in the patients with $\mathrm{HbA} 1 \mathrm{C}$ less than $6 \%$. Singer et al. they found that Long termed uncontrolled DM type2 patients even after Intensive glycemic control didn't seem to have decreased platelet activation which characterized DM ${ }^{(22)}$.Kodiatte et al. Reported that DM Patients have MPV positively correlated with $\mathrm{HbA1c}{ }^{(23)}$ which is contradicted with our findings because we have patient's glycemic control history just for the last 3 months not for entire drug using period which is a limitation in our study.

\section{Conclusion}

Increased Platelet indices (MPV, PLCR, and PDW) are signs of platelet activation and aggregation which play important role in the Prothrombatic state and accelerated atherosclerosis which characterize Diabetic type 2 patients. They were reduced among an oral hypoglycemic study group (Metformin and Glimepiride) than a non-diabetic population so Metformin and Glimepiride has good prognostic effect on the known Pro thrombatic state and accelerated atherosclerosis of DM but this effect were much more reduced among those using Metformin than patients taking Glimepiride as an oral hypoglycemic drug .

Also we concluded the platelet activation signs (increased MPV, PLCR and PDW) were reduced among those using Glimepiride with associated foot complications and platelet activation is important factor in wound healing in contrast to those taking Metformin. In other words Glimepiride is not drug of choice during diabetic foot Ulcers. Metformin is better for use during diabetic foot ulcers. However these results need further case control trails.

\section{List Of Abbreviations}




\begin{tabular}{|ll|}
\hline DM & Diabetes mellitus \\
\hline HbA1C & Hemoglobin A1c \\
\hline MPV & Mean platelet volume \\
\hline PLCR & platelet large cell ratio \\
\hline PDW & platelet distribution width \\
\hline SPSS & statistical package for the social sciences \\
\hline
\end{tabular}

\section{Declarations}

\section{Disclosure of potential conflicts of interests}

The authors declare that they have no conflict of interest, and no funding was received.

\section{Ethical approval}

All procedures performed in studies involving human participants were in accordance with the ethical standards of Khartoum State Ministry of Health Research Department ethical committee and with the 1964 Helsinki declaration and its later amendments or comparable ethical standards.

\section{Informed consent}

Informed consent was obtained from all individual participants included in the study.

\section{Data availability}

All data generated or analyzed during this study are available from the corresponding author on reasonable request.

\section{Author and co-author contribution}

All authors contributed to the study conception and design Material preparation, data and samples collection, and analysis were performed by Hussein Abker Hussein, Fatima-Elzhra Ahmed Elmagzoub , Dalia Mohammed Babikir, and Muona Adel Samaan. The first draft of the manuscript was written by Hussein Abker Hussein and all authors commented on previous version of the manuscript. All authors read and approved the final manuscript.

\section{Acknowledgements}

We would like to thank:

Jaber Abu Aliz diabetic Center staff , and people whom participated as Patients or controls. 
Khartoum state ministry of health researches department.

\section{References}

1. Kerner W, Brückel J. Definition, classification and diagnosis of diabetes mellitus. Experimental and clinical endocrinology \& diabetes. 2014 Jul;122(07):384-6.

2. Cdc.gov [internet].Atlanta: Centers for Disease control and prevention [updated 2019 May 30;cited 2020 December 9].Available from: https://www.cdc.gov/diabetes/basics/type2.html

3. Tripathi BK, Srivastava AK. Diabetes mellitus: complications and therapeutics. Medical science monitor. 2006 Jul 1;12(7):RA130-47.

4. Budak YU, Polat M, Huysal K. The use of platelet indices, plateletcrit, mean platelet volume and platelet distribution width in emergency non-traumatic abdominal surgery: a systematic review. Biochemia medica: Biochemia medica. 2016 Jun 15;26(2):178-93.

5. Tripathi BK, Srivastava AK. Diabetes mellitus: complications and therapeutics. Medical science monitor. 2006 Jul 1;12(7):RA130-47.

6. Zuberi BF, Akhtar N, Afsar S. Comparison of mean platelet volume in patients with diabetes mellitus, impaired fasting glucose and non-diabetic subjects. Singapore medical journal. 2008 Feb 1;49(2):114.

7. Park Y, Schoene N, Harris WJP. Mean platelet volume as an indicator of platelet activation: methodological issues. 2002;13(5-6):301-6.

8. Jindal S, Gupta S, Gupta R, Kakkar A, Singh HV, Gupta K, Singh S. Platelet indices in diabetes mellitus: indicators of diabetic microvascular complications. Hematology. 2011 Mar 1;16(2):86-9.

9. Schneider DJJDc. Factors contributing to increased platelet reactivity in people with diabetes. 2009;32(4):525-7.

10. Şahpaz F, Ulutaş KJDTD. Assessment of mean platelet volume in type 2 diabetics receiving insulin or oral antidiabetic agents. 2015;42(4):399-403.

11. Jindal S, Gupta S, Gupta R, Kakkar A, Singh HV, Gupta K, et al. Platelet indices in diabetes mellitus: indicators of diabetic microvascular complications. 2011;16(2):86-9.

12. Goraya TY, Leibson CL, Palumbo PJ, Weston SA, Killian JM, Pfeifer EA, Jacobsen SJ, Frye RL, Roger VL. Coronary atherosclerosis in diabetes mellitus: a population-based autopsy study. Journal of the American College of Cardiology. 2002 Sep 4;40(5):946-53.

13. Ferreiro JL, Gómez-Hospital JA, Angiolillo DJ. Platelet abnormalities in diabetes mellitus. Diabetes and vascular disease research. 2010 Oct;7(4):251-9.

14. Dib S, Makhous R. The Effect of Metformin on Mean Platelet Volume. Research Journal of Pharmacy and Technology. 2020;13(5):2329-34.

15. Dolasık I, Sener SY, Celebı K, Aydın ZM, Korkmaz U, Canturk Z. The effect of metformin on mean platelet volume in dıabetıc patients. Platelets. 2013;24(2):118-21. 
16. Papazafiropoulou A, Papanas N, Pappas S, Maltezos E, Mikhailidis DP. Effects of oral hypoglycemic agents on platelet function. Journal of diabetes and its complications. 2015 Aug 1;29(6):846-51

17. Xin G, Wei Z, Ji C, Zheng H, Gu J, Ma L, Huang W, Morris-Natschke SL, Yeh JL, Zhang R, Qin C. Metformin uniquely prevents thrombosis by inhibiting platelet activation and mtDNA release. Scientific reports. 2016 Nov 2;6:36222.

18. Yukio O, Yutaka Y, Shoji K. Effects of oral hypoglycaemic agents on platelet functions. Biochemical pharmacology. 1992 Aug 18;44(4):687-91.

19. Mardia Al, Gatot D, Lindarto D. Comparison platelet indices in diabetic patients with and without diabetic foot ulcer. InIOP Conference Series: Earth and Environmental Science 2018 Mar 1 (Vol. 125, No. 1, p. 012134). IOP Publishing.

20. BackSterner G, Carlson J, Ekberg G. Raised platelet levels in diabetes mellitus complicated with nephropathy. Journal of internal medicine. 1998 Dec;244(6):437-41.

21. Soulis T, Cooper ME, Vranes D, Bucala R, Jerums G. Effects of aminoguanidine in preventing experimental diabetic nephropathy are related to the duration of treatment. Kidney international. 1996 Aug 1;50(2):627-34.

22. Singer J, Snir AW, Leshem-Lev D, Rigler M, Kornowski R, Lev El. Effect of intensive glycemic control on platelet reactivity in patients with long-standing uncontrolled diabetes. Thrombosis research. 2014 Jul 1;134(1):121-4.

23. Kodiatte TA, Manikyam UK, Rao SB, Jagadish TM, Reddy M, Lingaiah HK, Lakshmaiah V. Mean platelet volume in type 2 diabetes mellitus. Journal of laboratory physicians. 2012 Jan;4(1):5. 